\title{
RAIL DELIVERIES OF BULK OIL CARGOES FROM THE CASPIAN REGION TO EUROPE
}

\author{
Erjan Akhmedov \\ Kazakh-British Technical University, 59, Tole bi str., Almaty, 050000, Kazakhstan, \\ e_akhmedov@hotmail.com
}

Keywords: Caspian region, Europe, rail transportation, crude oil, refined products

Abstract: This article is a study of the current situation with rail deliveries of bulk oil cargoes from the Caspian region to Europe. It addresses the importance of these deliveries for the European energy security, the salient features of rail transportation of crude oil and refined products in this direction, the main transportation routes, and, finally, describes existing and potential problems with rail deliveries of bulk oil cargoes from the Caspian region to Europe and suggests potential resolutions for these problems. In spite of the serious importance of the topic, the overall number of scientific publications related to it is limited. Another problem is that existing scientific literature sources tend to cover general transportation or geopolitical aspects without paying due attention to the rail transportation, logistical problems, related to the current topic, and how to resolve them. The author attempts to fill these knowledge gaps by collecting, processing, and analysing first-hand information from the main market players. The author concludes the article emphasising the importance of the railway transport for deliveries of bulk oil cargoes and pointing out that several important actions are required, namely the actual introduction of a competitive freight market and transition from transport to logistics corridors, support from governments and railway administrations and proactive position of shippers.

\section{Introduction}

The countries bordering the Caspian Sea include Azerbaijan, Iran, Kazakhstan, Russia and Turkmenistan. The map of the region is given in Figure 1 below.

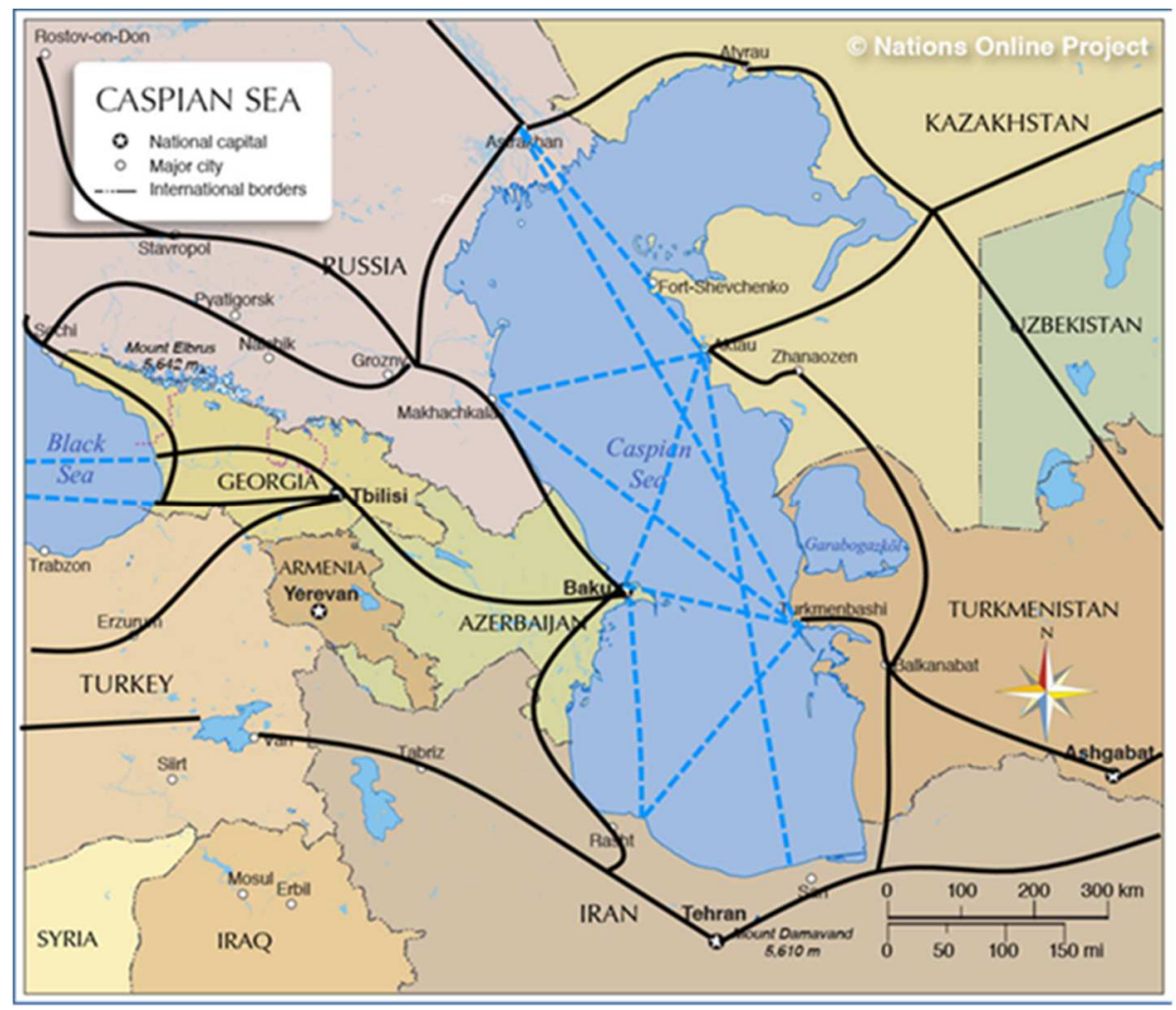

Figure 1: Caspian Sea region. Major railways and seaways

Source: [1] and own drawing 
One can ask if bulk oil supplies represented by crude oil and refined products from this region are important for Europe. Figure 2 and Figure 3 below give answers to this question, demonstrating that three out of five Caspian countries, namely Azerbaijan, Kazakhstan, and Russia, are among the largest crude oil and petroleum oils suppliers to the European Union (EU). Terms "refined product", "oil product" and "petroleum oil" are used interchangeably throughout this document. These facts clearly define the role of the region for European energy security. Iran is excluded from consideration because of the Western sanctions, which were tightened in 2019 [2]. This resulted in the discontinuation of Iranian crude supplies to the EU.

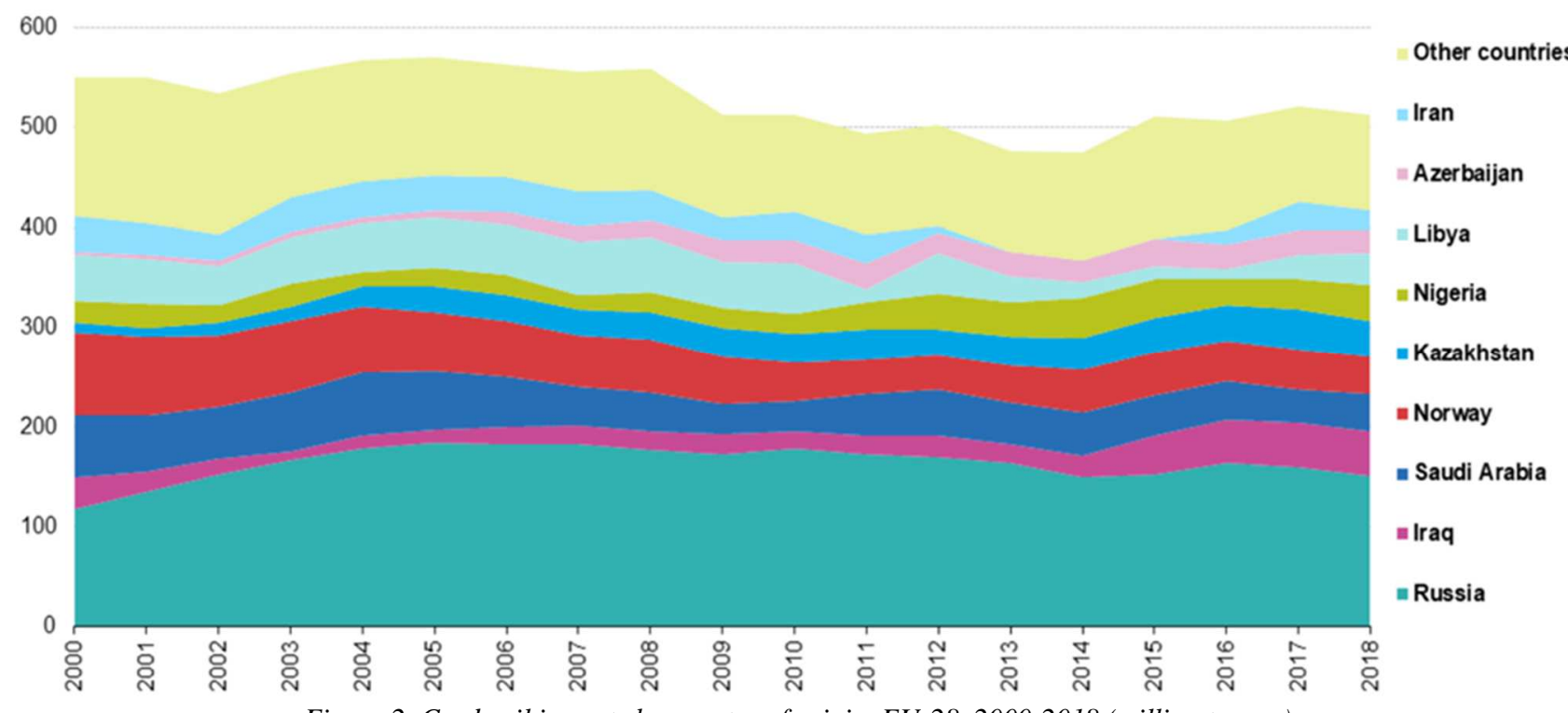

Figure 2. Crude oil imports by country of origin, EU-28, 2000-2018 (million tonnes)

Source: [3]

2018

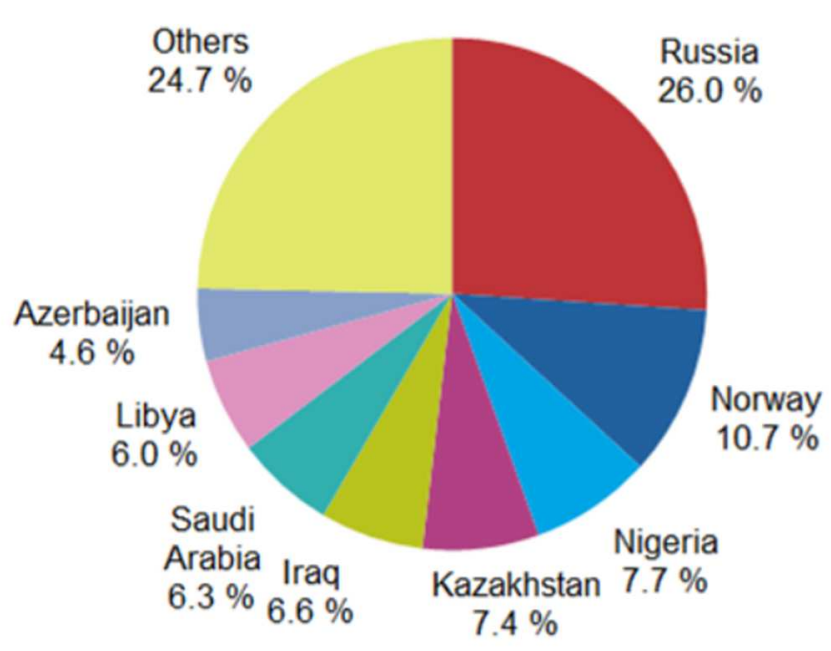

2019

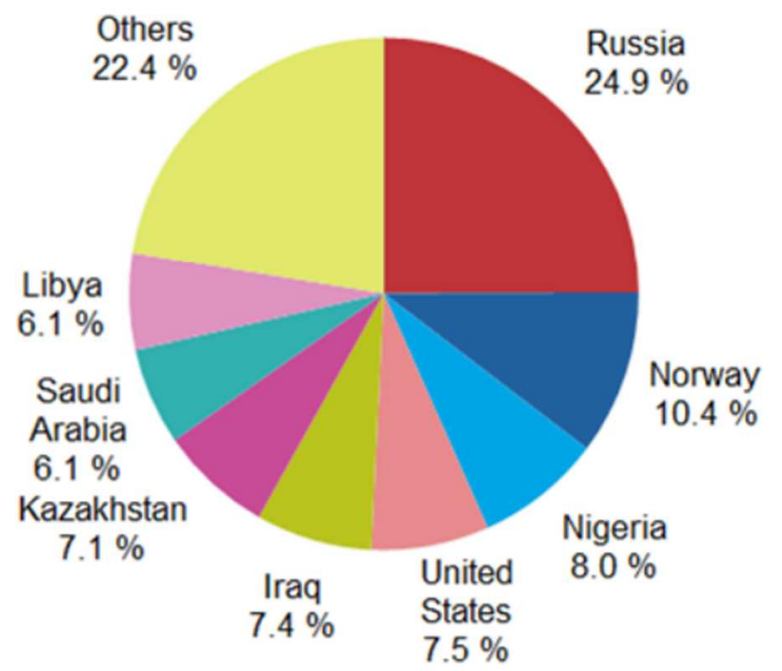

Figure 3. Extra-EU imports of petroleum oils from main trading partners, 2018 and 2019 (share (\%) of trade in value). Source: [4]

This dependence is mutual. [5] pointed out that "The economy of the Caspian region depends on energy economy of Europe depends on energy imports, while the exports." 
RAIL DELIVERIES OF BULK OIL CARGOES FROM THE CASPIAN REGION TO EUROPE

Erjan Akhmedov

Even though this region is one of the closest to Europe geographically, the distance between them is huge and measured in thousands of kilometres. This defines the significance of transportation in general and of railways in particular. It is also important to note that ,An important aspect of the European policy is to enhance the role of railway transport" [6].

The following knowledge gaps exist at the moment, and this is shown in the Literature Review section below:

1. In spite of serious importance of the topic, the overall number of scientific publications, especially in English, related to the rail deliveries of bulk oil cargoes from the Caspian region to Europe is limited;

2. Existing scientific literature sources tend to cover general transportation or geopolitical aspects without paying due attention to the rail transportation, logistical problems, related to the current topic, and how to resolve them.

This article attempts to close these gaps.

The research questions follow from these knowledge gaps and may be summarised as follows:

1. What are existing and potential problems related to rail deliveries of bulk oil cargoes from the Caspian region to Europe?

2. What are the ways to resolve these problems?

\section{Literature review}

Rail deliveries of bulk oil cargoes from the Caspian region to Europe are not in the limelight of researchers. However, the author has collected and reviewed as many sources as possible. He also widely used information gathered at oil and transportation conferences and other professional events he attended over the past few years.

As already mentioned above, the number of scientific publications addressing the topic is small. They, however, exist and are listed here. It is interesting to note that back in the 90s [7] complained that "too much oil to ship by rail or barge; pipelines are more efficient and less expensive options for carrying cargo across great distances". The situation now is completely different and will be described further below.

A substantial part of scientific publications related to the topic of this article are in Russian. They include the works of [8-16] and of many others. We should note the work of [17] about export deliveries of oil and petroleum oils separately. He considered flows, routes and transport mode's competition. This work forecasted the decrease in rail deliveries by 2020, and this forecast materialised. [18] provided a comprehensive analysis of oil and oil products flows via Russian maritime ports.

Also, the author managed to find many interesting scientific publications on the topic written in English as well. Among deserving due attention are the publications by [19] who examined "the ways in which CIS oil industries have been organised and governed since 1991, as well as questions of transport infrastructure and export routes, which are especially critical for Central Asia's landlocked producers." In their another publication [20] concluded that "policy-makers can do much to raise or lower the long-term elasticity of CIS supply. Unfortunately, policy in the region seems, on present trends, likely to lower it." This point is still valid after more than ten years. [21] addressed a whole range of issues related to the Trans-Caspian energy route, including "the implications of the August 2008 crisis in Georgia for the prospects of the expansion of the westbound route and for the future of Caspian energy export routes in general”, ,the complex relationship between Azerbaijan and Kazakhstan and their companies involving rivalry, competition and cooperation in the westward oil export", etc. [22] reiterated that "European markets represent the most profitable option for the export of Azerbaijani oil and gas". [23] mentioned that "the EU and Kazakhstan agreed in January 2015 to initiate a new "Enhanced Partnership and Cooperation Agreement". But the energy field has not explicitly been defined as one of the "main areas of cooperation' despite Kazakhstan being the third-largest non-OPEC supplier to the EU." [24] examined "alternative transportation lines in the (Caspian) region, reveal the current problems, and propose solutions within the context of infrastructure or transport policies."

It is necessary to mention that a substantial portion of scientific publications is devoted to the geopolitical aspects of crude and oil products supplies from the Caspian region to Europe. Such works include [25-29] and many other. We should also mention [30] who analysed "how the security of oil supply to the European Union member states could be enhanced in case of a lasting supply disruption..." and found that "Ultimately, this depends on the ability to feed a sufficient amount of refining capacity, which would in turn supply refined products to the market." [5] examined ,the security of demand for the oil and gas of three countries in the Caspian region".

Some scientists investigated the significance of Caspian hydrocarbon supplies for the EU. [31] wrote that „West European countries perceive increasing their supplies from the Caspian region as a way to lessen their dependence on oil coming from OPEC-associated countries, especially the Persian Gulf." [32] advised that „Caspian energy resources have the potential to substantially diversify Europe's energy supplies away from a current over-dependence on Russia. If supported by the appropriate policies, Europe has the potential to, in several years, emerge as better-situated and stronger vis-àvis Russian energy dominance."

Researchers addressed the issue of improper development of transport and logistics services in the region. For example, [33] examined "Russia's entire oil and gas export network and reveals that there is a considerable surplus pipeline capacity, which is likely to endure in the future. It brings to attention surplus capacity as a concept..." It is obvious that the excess pipeline throughput 
capacity has negatively affected the volumes transported by rail.

Though very limited in number, some publications still describe and analyse the rail transportation of oil and oil products. They include the already mentioned excellent report on the Caucasus Transport Corridor prepared by the World Bank: 'This study evaluates the potential demand for oil and oil products transport via the existing rail corridor in the Caucasus, considering the competition from alternative routes” [34]. [35] who points out that „From the point of view of the operation of railway transport, oil and oil products occupy a large share in cargo operations, but an even larger share in Russian Railways' income”. This point is echoed by $[36,37]$, who wrote that „One of the most important segments of the transport market of the Republic of Kazakhstan is the transportation of oil cargo".

As mentioned earlier, transportation of crude and petroleum oils from the Caspian region to Europe has received limited attention from researchers. This is why the author used other sources of information. The most interesting and reliable sources include publications of Eurostat, international organisations and financial institutions, oil companies and specialist journals.

\section{Methodology}

The descriptive part of the article (Current situation) is based on the review of different literature sources as well as on the information gathered at oil and gas conferences and other professional events. In 2019 and 2020, the author attended and spoke at various professional events in Azerbaijan, Hungary, Kazakhstan, the Netherlands and Russia.

The part devoted to existing and potential problems related to the topic is mainly based on in-depth semistructured one-to-one interviews through literature sources were also used. In 2019 and 2020, the author interviewed 20 individuals working for oil and transportation companies and traders, i.e., those involved in the transportation of oil bulk cargos from the Caspian region to Europe. 14 out of 20 interviews were face to face. The rest took place via VoIP applications (WhatsApp and Skype).

The list of interviewees is given in Appendix A below. The sample is representative because the author approached most of the main market players. Please note that this is qualitative research, so the data obtained are non-numerical. This research had the following main steps:

- Collecting information through the relevant literature review;

- Collecting information through interviews;

- Transcribing and cross-checking the answers;

- Analysing the answers and the information collected through the relevant literature review;

- Summarising the collected information.

The respondents (terms "interviewee" and "respondent" are used interchangeably throughout this document) were requested to (i) list and describe the main problems shippers face in the process of rail transportation of crude and oil products to Europe and (ii) suggest ways to resolve them.

The answers on the first question were cross-checked to ensure their trustworthiness. The answers to the second question were not cross-checked as they represent not the real situation but rather the ways to change it. However, the interviewees were asked to give their opinion on potential solutions proposed by others. Several follow-up calls were made in order to clarify and ascertain the information.

Limitations of this research are described in Conclusions.

In 2019 and 2020, the findings described in this article were reported at the professional oil events in the countries mentioned above and were positively accepted.

\section{Current situation \\ 4.1 Rail transportation of oil cargoes}

The points below are important for understanding the transportation of crude oil and petroleum oils from this region to Europe by rail:

- Railways are used for transportation of a major part of refined products and of a smaller part of crude oil transportation. This is also the only mode used for transporting sulphur, which is a by-product from sour crude oil and gas processing. In case of crude transportation, rail is used in the absence of direct access to pipelines or tankers and in the situations when a producer wishes to retain quality and consequently the value of its crude since there is no quality bank in the Russian crude oil pipeline network;

- Rail volumes of bulk oil cargoes have been decreasing over the last years. Mainly because of large-scale construction of new oil product pipelines in Russia and obscure rail rate policy "The share of oil and refined products (in the total shipments of Russian railways) continues to decline: in 2016 it was $19.3 \%$, in $2017-18.7 \%$, and at the end of 2018 it reached 18.3\%" though they remain "...the second largest cargo for Russian Railways" [35];

- Railways not only compete but also serve as a backup option in case of problems with pipelines. The last case was in April-June 2019 when organic chlorides contaminated parts of the Russian crude oil pipeline network;

- There is the strongest influence of political situation on transportation routes;

- The attention of governments and railway administrations of the region is focused on attracting transit traffic;

- The regional railway and trans-shipment infrastructures are undergoing continuous improvement. Large infrastructure investments have been made since the dissolution of the former Soviet 
Union. However. there are significant imbalances as the current usage of the regional railway, and oil trans-shipment infrastructure is far from optimal;

- Multimodal (pipeline or rail and then marine) is the main mode of crude oil and oil products transportation from this region to Europe;

- Rail deliveries are certainly more expensive than marine or pipeline transport, but their importance remains significant, which will be described further below.

\subsection{Main routes}

This section describes the crude oil and refined products rail deliveries through the example of each country.

Azerbaijan: Crude oil is transported by rail to the Georgian Black Sea ports in relatively small volumes as the main crude oil goes via pipelines. Azeri and much smaller volumes of Kazakh and Turkmen products are railed to Georgia's Black seaports. After reaching seaports, crude and refined products are transshipped onto tankers and then delivered to European ports.

Iran: As mentioned above, this country is excluded from consideration because of the Western sanctions.

Kazakhstan: Since the collapse of the former USSR, the country has built more railways than any other postSoviet country. Kazakhstan, the main crude oil producer in the Caspian region, exports most of its crude oil to the European markets. In the case of rail deliveries, Kazakh crude and products mostly go to Russia's Black Sea ports. Smaller amounts are delivered to Russia's Baltic Sea ports. The ports of such countries as Estonia, Latvia and Lithuania are also used, but this traffic is decreasing. Georgia's Black Sea ports are used as well, especially in winter periods, though the logistics of this route is cumbersome.

Russia: The country is the main producer of products in the Caspian region, though, as mentioned above, its crude production in the Caspian region is relatively small. Russia is also the biggest transiter in the region thanks to its geography, and it exercises this advantage to the full extent. It also has a well-developed and comprehensive transport infrastructure. In addition to its geographic advantages, the country adopted the state policy of diverting transit traffic to the Russian seaports already mentioned above. As a result, "since 2013 a large part of Russian foreign trade cargo flows has been forwarded from the ports of Ukraine and the Baltic countries to the domestic ports" (Ivin, Goryacheva and Kurbatskii, 2020).

Turkmenistan: The country possesses enormous hydrocarbon reserves, especially natural gas, and is actively developing its railway infrastructure. The main problem is that Turkmenistan is very distant from the main consumers. Turkmen crude is shipped by sea to Baku, Azerbaijan or Makhachkala, Russia. Small volumes of Turkmen petroleum oils are shipped by tankers to Russian or Ukrainian Black Sea ports (via the Volga-Don canal) or to Baku and then railed.

\section{$5 \quad$ Result and discussion}

This part of the article describes main problems complicating rail transportation of crude oil and refined products from the Caspian region to Europe and the ways to resolve them and was mainly prepared based on the responses of the interviewees listed in Appendix A below.

\subsection{Main problems}

(1) Monopolism and intermediaries: All the railways in the region are state-owned and represent natural monopolies. All the respondents declined to talk about intermediaries openly but hinted that they (intermediaries) enjoy full support in high echelons of power of the Caspian states. (Lawrence et al., 2008) mentioned in this regard that "the unusually high share of revenues that appears to be going to intermediaries compared to actual service providers. ... an estimated third of revenues goes to intermediaries. By contrast, in Europe and North America, freight forwarders typically earn three percent of revenues". This problem was reported by 15 out of 20 interviewees. Interestingly, some of them represent these monopolists or intermediaries;

(2) Growth of railway rates: Rates grow regularly, but crude oil prices do not. On the contrary, crude oil prices decreased since 2014 significantly, and so did oil companies' revenues. One of the interviewees noted in this regard: "Railroads are used to perceive oil companies as cash cows. This is no longer the case. Constantly raising rail rates, they work against themselves". Another shippers' serious concern is that, in their view, a bigger part of railroad revenues has to be invested in the improvement of rail infrastructure and rolling stock, but this is not happening. 17 out of 20 interviews informed about this problem;

(3) Obscure railway rate-setting policy: As one of the interviewees mentioned, "In a perfect world, the quality of services and the rail rates for the transportation of oil and products should discourage oil producers from using alternative modes of transport. In reality, two companies from the same region often receive different rates to the same destination. This situation forces oil producers to look for alternatives". The same amount of respondents mentioned this problem (17 out of 20 );

(4) Decrease of rail volumes of bulk oil cargoes: As mentioned above, these volumes have been decreasing over the last years. As a result, it is becoming more difficult to negotiate reduced rail rates for regional shippers, and this has become a serious concern for all the interviewees (20 out of 20);

(5) Strong influence of the political situation on transportation routes: Expectedly, the respondents refused to comment on this point even though some of them (12 out of 20) hinted at difficulties with rail shipments to 


\section{RAIL DELIVERIES OF BULK OIL CARGOES FROM THE CASPIAN REGION TO EUROPE}

Erjan Akhmedov

Europe via the Ukrainian territory since 2014 when the Russian-Ukrainian conflict began.;

(6) Difficult weather conditions of the Caspian (up to 90 days per year on average): Even though this problem is natural, it still creates a lot of problems for shippers. Adverse weather conditions (sea storms) often prevent departures of tankers, which lead to violations of railcars delivery schedules, large downtimes, etc. This problem was reported by 10 out of 20 interviewees;
(7) Significant losses when emptying rail tank cars: Talking about this problem, the respondents (10 out of 20) admitted that it is mostly caused by negligence and the use of rail tank cars without heating systems or with defective heating systems used in winter periods.

Figure 4 below provides the graphical representation of the information described in this paragraph.

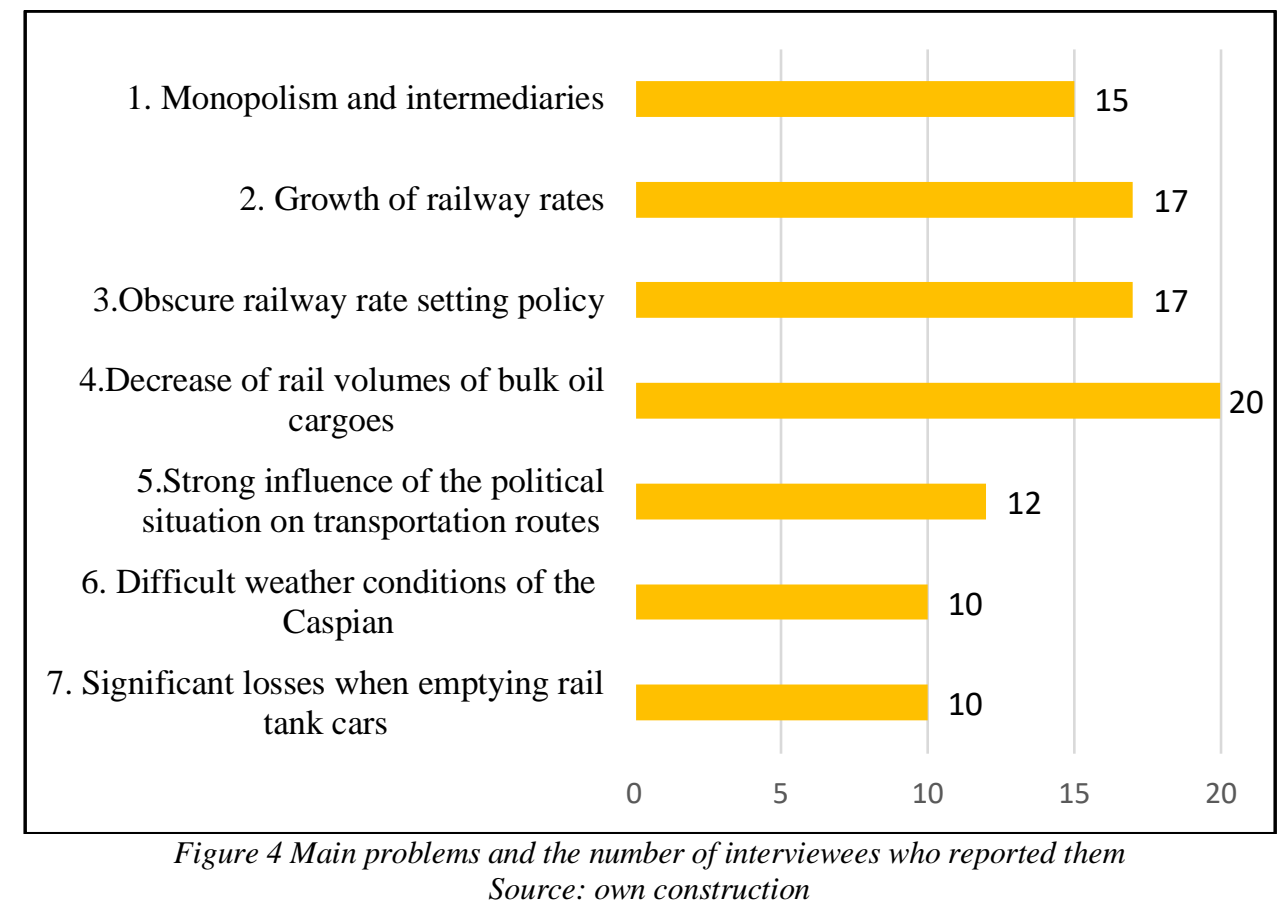

\subsection{Ways to resolve problems}

The interviewees suggested the following ways to resolve the problems listed above:

(1) Transition from transport to logistics corridors (a logistics corridor is the second stage of corridor development where establishing physical links to an area are accompanied by the harmonisation of the institutional framework): Most of the respondents (14 out of 20) actively supported this idea. Their common vision is that joined efforts of shippers, railway and port administrations and national governments can improve the situation substantially;

(2) Actual introduction of a competitive freight market: There was a consensus that this is a long-awaited and largely belated measure, which can remedy the situation greatly. 15 out of 20 respondents supported this idea. Another consensus was that the respondents do not expect this measure to be implemented soon though the delay with its introduction is damaging for the regional economies.;

(3) Proactive position of shippers: 11 representatives of oil companies and shippers complained that oil producers and shippers have no unified and proactive position. This is not a problem for big oil companies, which are strong enough to defend their interests. However, smaller companies and shippers suffer, so they should unite their efforts to improve their situation;

(4) Support from the governments and the railway administrations: 15 representatives of oil companies and traders repeatedly stressed that oil prices are no longer of US $\$ 140$ per barrel. In the situation when oil prices are mostly below US\$60 per barrel, it is now the turn of regional governments and railway administrations to support the oil shippers;

(5) Strong influence of the political situation on transportation routes: the solution to this problem is the prerogative of politicians. Respondents generally declined to comment anything else on this point;

(6) Difficult weather conditions of the Caspian: The respondents consider this circumstance as acts of God and do not consider this problem as a major one because the overall transit via the Caspian Sea is relatively small;

(7) Reduction of losses: This measure is obvious and was just mentioned. In general, the interviewees do not consider this problem as a serious one.

The respondents were generally less active in discussing solutions to the problems. Two main reasons 
may explain this: (i) the current situation is the most favourable for some of them and (ii) all of them are in one, or another way are bound by confidentiality obligations and cannot discuss every matter related to their work.

There is no graphical representation of the problems' solutions because all the interviewees refused to discuss point (5) as well as anything related to politics, and points (6) and (7) caused very little interest on their side.

Initially, the intent was to present the problems and the ways to resolve them in a tabular form. However, this way appeared to be inconvenient because the same measure is often a resolution to several problems. For example, measure (2) serves as a resolution to the problems (1), (2), (3) and (4). Importantly, the respondents insisted that a package of measures only can improve the situation.

\section{Conclusions}

There are several main points, which should be considered as conclusions to this article:

- Railway transportation of oil and refined products remains and will continue to be an important transportation option and, in some cases, the only possibility;

- The role of railway transport is extremely significant as a backup option for pipeline transport;

- The regional countries should commence the actual introduction of a competitive freight market and transition from transport to logistics corridors soon;

- Support from governments and railway administrations is particularly essential;

- The proactive position of shippers in the form of a transport union or association can help smaller oil companies and independent shippers.

The author of this article acknowledges the limitations of his research, which are caused by this market's private and confidential nature. This circumstance forced the interviewees to observe strict professional confidentiality obligations and self-censorship. The research's strengths include the scientific novelty of the topic, receiving firsthand information from the market players directly and the importance of the topic for European energy security. There is certainly a need for more research on the topic, and the author is planning to study it in more detail.

\section{Research limitations}

Limitations of this research are related to the following:

- Sample size: The situation is that the overall number of market players is limited. Another consideration is that this is qualitative research where the sample size is generally less relevant than in the quantitative type of research;

- Self-reported data: This limitation was addressed through cross-checking the answers and using literature sources where possible;
- $\quad$ Private and confidential nature of this business: This nature causes the respondents' professional confidentiality obligations and self-censorship. This limitation was addressed through (i) strict anonymity of respondents and (ii) warning them from the beginning that they have to avoid any sensitive issues. As a result, the interview processes went quite smoothly.

The limitations above do not downplay the cognitive value of the research as they pertain to the subject matter of this article.

\section{References}

[1] NATIONS ONLINE PROJECT, Map of the Caspian Sea, [Online], Available: https://www.nationsonline.or g/oneworld/map/Caspian-Sea-map.htm

[09 Nov 2020], 2020.

[2] FINANCIAL TIMES, What does the end of US waivers on Iran's oil exports mean?, [Online], Available: https://www.ft.com/conte nt/5c14b88e-651b-11e9-a79d-04f350474d62

[09 Nov 2020], 2020.

[3] EUROSTAT, Crude oil imports by country of origin, EU-28, 2000-2018, [Online], Available: https://ec.europa.eu/eurostat/statistics-

explained/index.php?title=File:Crude_oil_imports_by _country_of_origin,_EU-27,_2000-

2018_(million_tonnes)_F.png. [09 Nov 2020], 2020.

[4] EUROSTAT, Extra EU imports of petroleum oil from main trading partners, 2018 and 2019, [Online], Available: https://ec.europa.eu/eurostat/statisticsexplained/index.php?title=File:Extra-

EU_imports_of_petroleum_oil_from_main_trading_p artners,_2018_and_2019_v2.png [09 Nov 2020], 2020.

[5] AYDIN, U., AZHGALIYEVA D.: Assessing Energy Security in the Caspian Region: The Geopolitical Implications for European Energy Strategy, ADBI Working Paper, No 1011, Tokyo, [Online], Available: https://www.adb.org/publications/assessing-energysecurity-caspian-region, [09 Nov 2020], 2019.

[6] DOLINAYOVA, A., CAMAJ J., KANIS, J.: Charging Railway Infrastructure Models and Their Impact to Competitiveness of Railway Transport, Transport Problems, Vol. 12, No. 1, pp. 139-150, 2017. doi:10.20858/tp.2017.12.13

[7] CROISSANT, M. P., ARAS, B.: Oil and geopolitics in the Caspian Sea Region. Westport, Greenwood Publishing Group, 1999.

[8] TEVZADZE, Z.: Export routes and problems of Caspian oil transportation, Central Asia and the Caucasus, [Online], Available: https://www.cac.org/journal/2004/journal_rus/cac-01/12.tevrus.shtml, [09 Nov 2020], 2004. (Original in Russian).

[9] MAKAROVA, S.: Export routes and transportation of Caspian oil and gas, Social and economic geography, [Online], Available: https://cyberleninka.ru/article/n/2 
005-03-011-014-eksportnye-marshruty-itransportirovka-kaspiyskoy-nefti-i-gaza, [09 Nov 2020], 2005. (Original in Russian)

[10] PETROV, M., LUBENKO, V.: The Forecast of the Marine Oil and Gas Development and the Possible Method of Oil Transportation on the Shelf of the North Caspian Sea, Bulletin of the Astrakhan State Technical University,[Online], Available: https://cyb erleninka.ru/article/n/perspektivy-morskoy-dobychinefti-i-gaza-na-shelfe-severnogo-kaspiya-ivozmozhnye-sposoby-ih-transportirovki, [09 Nov 2020], 2008. (Original in Russian)

[11] PETROV, M., LUBENKO, V.: Factors Influencing the Choice of Optimal Caspian Sea Shelf Hydrocarbon's Transportation, Bulletin of the Astrakhan State Technical University, [Online], Available: https://cyberleninka.ru/article/n/ faktory-opredelyayuschie-optimalnuyu-shemutransportirovki-uglevodorodov-shelfa-kaspiyskogomorya, [09 Nov 2020], 2009. (Original in Russian)

[12] MARKUSHINA, E.: Economic and regional factors in the development of hydrocarbon transportation systems, Scientific and technical statements of St. Petersburg State Polytechnic University. Economics, [Online], Available: https://cyberleninka.ru/article/n/ ekonomicheskie-i-regionalnye-faktory-razvitiyasistem-transportirovki-uglevodorodov, [09 Nov 2020], 2011. (Original in Russian)

[13] SMIRNOVA, A.: Features of the development of transportation of oil and oil products by various modes of transport, Bulletin of Kazan Technological University, [Online], Available: https://cyberleninka. ru/article/n/osobennosti-razvitiya-perevozki-nefti-inefteproduktov-razlichnymi-vidami-transporta, [09 Nov 2020], 2012. (Original in Russian)

[14] SHAIKHUTDINOVA, F.: Export strategy of the oil and gas complex of Turkmenistan: status and prospects, Bulletin of Kazan Technological University, [Online], Available: https://cyberleninka. ru/article/n/eksportnaya-strategiya-neftegazovogokompleksa-turkmenistana-sostoyanie-i-perspektivy, [09 Nov 2020], 2014. (Original in Russian)

[15] AKHMETOVA, Z. B., KOZHAMKULOVA, Z. T., TURLYBEKOVA, N. M.: Development of transport infrastructure of Kazakhstan: problems and prospects, Kazakh National University Bulletin, [Online], Available: https://articlekz.com/article/153 65, [09 Nov 2020], 2015. (Original in Russian)

[16] SHMULEVICH, M.: Transport Infrastructure of Russia's Oil and Gas Industry, Transport of the Russian Federation. Journal of Science, Practice, Economics, Vol. 73, No. 6, pp. 36-44, 2017. (Original in Russian)

[17] SHCHERBANIN, Yu.: Export Deliveries of Oil and Petroleum Products: Flows, Routs, Transport Mode's Competition, Design, Construction and Operation of Gas and Oil Pipelines and Storages, Vol. 1, pp. 22-
27, 2017. (Original in Russian)

[18] SHCHERBANIN, YU., GOLYZHNIKOVA D.: Export Cargo Flows via Russian Maritime Ports: Oil Cargo - Some Considerations, Russian foreign economic herald, Vol. 4, pp. 18-36, 2019. (Original in Russian)

[19] AHREND, R., TOMPSON, W.: Realising the Oil Supply Potential of the CIS: The Impact of Institutions and Policies, OECD Economics Working Paper series, No. 485, pp. 1-84, 2007. doi:10.2139/ssrn.1010667

[20] AHREND, R., TOMPSON, W.: Caspian oil in a global context, Transition Studies Review, Vol. 14, No. 1, pp. 163-187, 2007. doi:10.1007/s11300-007$0132-5$

[21] GULIYEV, F., AKHRARKHODJAEVA, N.: The Trans-Caspian energy route: Cronyism, competition and cooperation in Kazakh oil export, Energy Policy, Vol. 37, No. 8, pp. 3171-3182, 2009. doi:10.1016/j.enpol.2009.04.009

[22] MKRTCHYAN, T., HUSEYNOV, T., GOGOLASHVILI, K.: The European Union and the South Caucasus: Three Perspectives on the Future of the European Project from the Caucasus, Gütersloh, Bertelsmann Stiftung, [Online], Available: http://aei.pitt.edu/11116/1/xcms_bst_dms_28297_28 302_2.pdf, [09 Nov 2020], 2009.

[23] UMBACH, F., RASZEWSKI, S.: Strategic Perspectives for Bilateral Energy Cooperation between the EU and Kazakhstan - Geo-economic and Geopolitical Dimensions in Competition with Russia and China's Central Asia Policies, Berlin, Konrad Adenauer Stiftung, [Online], Available: https://www.researchgate.net/publication/296677558 _Research_Study_Strategic_Perspectives_for_Bilate ral_Energy_Cooperation_between_the_EU_and_Ka zakhstan_-_Geo-

economic_and_Geopolitical_Dimensions_in_Compe tition_with_Russia_and_China's_Central, [09 Nov 2020], 2016.

[24] ACAR, A. Z., GÜROL, P.: An innovative solution for transportation among Caspian region, Procedia Social and Behavioral Sciences, $5^{\text {th }}$ International Conference on Leadership, Technology, Innovation and Business Management, Vol. 229, pp. 78-87, 2016. doi:10.1016/j.sbspro.2016.07.116

[25] BAHGAT, G.: Pipeline Diplomacy: The Geopolitics of the Caspian Sea Region, International Studies Perspectives, Vol. 3, No. 3, pp. 310-327, 2002. doi:10.1111/1528-3577.00098

[26] AMINEH, M. P., HOUWELING, H.: Global energy security and its geopolitical impediments - The case of the Caspian region, Perspectives on Global Development and Technology, Vol. 6, No. 1-3, pp. 365-388, 2007. doi:10.1163/156914907X207793

[27] TSERETELI, M.: Economic and Energy Security: Connecting Europe and the Black Sea-Caspian 
Region, Central Asia-Caucasus Institute \& Silk Road Studies Program publication, Washington, D.C., Available: https://www.files.ethz.ch/isn/48482/30_E conomic\%20and\%20energy\%20security.pdf [09 Nov 2020], 2008.

[28] IBRAYEVA, A.: Importance of the Caspian Countries for the European Union Energy Security, International Journal of Energy Economics and Policy, Vol. 8, No. 3, pp. 150-159, 2018.

[29] RAIMONDI, P.: Central Asia Oil and Gas Industry The External Powers' Energy Interests in Kazakhstan, Turkmenistan and Uzbekistan, Fondazione Eni Enrico Mattei Working Paper Series, Milan, No. 006.2019, Available: https://www.feem.it/m/publications_pages/ndl2019006.pdf [09 Nov 2020], 2019.

[30] KOTTSIEPER, N.: Study on the Technical Aspects of Variable Use of Oil Pipelines-Coming into the EU from Third Countries Overall Report Prepared for the Directorate-General for Energy of the European Commission, ILF Consulting Engineers, Purvin \& Gertz, Munich, [Online], Available: https://ec.europ a.eu/energy/sites/ener/files/documents/2010_reportin g_technical_aspects.pdf, [09 Nov 2020], 2010.

[31] CICHOCKI, J.: The Significance of Caspian Oil and Gas for Diversifying Energy Imports to the Visegrad Group Countries, Connections, Vol. 2, No. 1, pp. 2328, 2003.

[32] LUPU, C.: The Russia and EU at crossroads. The role of the Black Sea region in the European energy security, Università Degli Studi di Trieste, Trieste, [Online], Available: https://core.ac.uk/download/pdf /41172151.pdf [09 Nov 2020], 2009.

[33] VATANSEVER, A.: Is Russia building too many pipelines? Explaining Russia's oil and gas export strategy, Energy Policy, Vol. 108, pp. 1-11, 2017. doi:10.1016/j.enpol.2017.05.038

[34] LAWRENCE, M., MELIBAEVA, S., MOOSE, J.: Caucasus Transport Corridor for Oil and Oil Products, The World Bank, Washington D.C., [Online], Available: https://openknowledge.worldba nk.org/handle/10986/12309? show=full [09 Nov 2020], 2008.

[35] KHUSAINOV, F., OZHERELEVA, M.: Freight transportation: about the transportation of goods of the fuel and energy complex by rail in 2018, Railway economics, Vol. 2019, No. 8, pp. 70-84, 2019. (Original in Russian)

[36] DUYSEKEEV, N.: Transportation of Oil Cargo by Railway Transport in the Republic of Kazakhstan,
Collection of scientific papers of the Kazakh Academy of Transport and Communications, [Online], Available: https://www.kazatk.kz/material/ nauka/practica1/379-382.pdf, [09 Nov 2020], 2017. (Original in Russian)

[37] IVIN, E., GORYACHEVA, A., KURBATSKII, A.: State Analysis and Development Prospects of Cargo Traffic Through the Sea Ports of Russia, Problems of Territory's Development, Vol. 106, No. 2, pp. 62-80, 2020. doi:10.15838/ptd.2020.2.106.5 (Original in Russian)

\section{Appendix A}

\section{List of interviewees}

1. Head of transport operations, international oil company, operating in Kazakhstan;

2. Senior Business development manager, Russian oil trading company;

3. Vice-president for operations, Russian transportation company;

4. Head of export operations, a small Russian oil company;

5. Representative, Kazakhstan Association of Carriers and wagon operators;

6. Head of the export department, a Kazakh oil company;

7. Senior specialist, transportation and marketing department, a Kazakh oil company;

8. Deputy director-general for commerce, a Ukrainian oil company;

9. Transport manager, international shipping operator;

10. Commercial manager, a Lithuanian oil company;

11. Director general, Russian oil trading company;

12. Transport manager, a Kazakh oil company;

13. CEO, Azeri oil trading company;

14. Manager, Turkmen oil company;

15. Head of division, Azerbaijan Railways;

16. Representative in Azerbaijan, Georgian oil trading company;

17. Transport manager, international oil trading company;

18. Head of the transportation department, European oil company, operating in Kazakhstan;

19. Manager, oil market intelligence agency;

20. Manager, Russian Black seaport administration.

\section{Review process}

Single-blind peer review process. 